\title{
CORPORATE GOVERNANCE MODEL IN UKRAINE: THE CONFLICT RESOLUTION PROBLEMS
}

\author{
OLGA NOSOVA
}

\begin{abstract}
University of Banking Kharkiv Institute of Banking, Ukraine
e-mail: nosovaov@yahoo.com

RECEIVED

16 March 2015

ACCEPTED

1 August 2015

JEL

CLASSIFICATION

G34

KEYWORDS

corporate governance, conflicts resolution, financial management, stakeholders

ABSTRACT

The purpose of the article is to examine whether there is a corporate governance model that could minimize the negative effects of conflicts, align of managers' behavior with stockholders, and provide stock markets development. The analysis of numerous studies helps to clarify the basic issues including objectives, interests, methods of achievement, and benefits of managerial and stakeholder conflicts. The corporate sector development demonstrates the use of mixed model in Ukraine, based partly on the application of the principals of American, and German models of corporate governance.

The causes of corporate governance conflicts are considered in Ukraine. The application of the economic and legal mechanisms for corporate conflicts elimination is proposed. Specific policy proposals designed to achieve the goal to separate regulators from company management and owners. Governance must clearly define the functions and relationships of the various parties, and separate oversight from operational and financial management. The public accountants objectivity can be introduced in Ukraine through creation of institutional structures that define and require regulation, records, and audit. In the new context, auditors will be private contractors serving as regulators, and they will work for boards of directors. Management is not involved.

The article analyses the measures that have been taken to create an effective corporate governance model in Ukraine. The international accounting standards application, based on American and European accounting standards in corporate governance, will be directed to create mechanism for disclosures and frauds preventing in all companies. The national accounting agencies foundation in East European countries, including Ukraine will provide the adoption of international accounting standards at the country's level.
\end{abstract}

\section{Introduction}

The study and analysis of contemporary trends in the development of the corporate sector indicates the concentration of ownership in the hands of financial and industrial groups. Foreign banking institutions dominate in the financial sector. The national currency devaluation, the outflow of deposits, the lack of liquidity, the reduction of the loan portfolio, and reduction of bank reserves are among the challenges faced by the banking system of 
Ukraine. Business activity decreases due to the unstable situation in Ukraine in the corporate sector, which is accompanied by the outflow of foreign direct investment from the country which is amounted to $\$$ US 8 billion from September 2013 to September 2014 (Wirtschaftsinformationsdienst, 2014). The state attracts and uses the significant leverage of the corporate sector. Implementation of the strategy of increasing the corporate sector share in the total portfolio of financial institutions is seen as a generator of corporate activity and the foundation for rapid recovery of the Ukrainian economy.

Scientists focus their attention to shareholders (owners) and stockholders' interests, models of inside and outside board committee, and a relationship between governance practices, and corporate or organizational performance. Some authors emphasize the discussed issue which is related to the interdependence of global financial crisis and efficiency of corporate governance system. The basic approaches deal with an absence of correlation between corporate governance and financial crisis, an effective implementation of existing corporate governance arrangements and principles.

In a broad sense, "corporate governance system" refers to the whole set of regulatory, market stakeholder and internal governance. Significant correlation between corporate governance and financial infrastructure has not been estimated. Using a panel data of 44 developed and developing countries, K. Ojah, T. Mokoaleli-Mokoteli analyze the macro-environmental determinants of Internet financial reporting (IFR) within the context of corporate governance models. Scientists consider both physical and institutional infrastructures to be important determinants of a country's adoption of IFR (Ojah, Mokoaleli-Mokoteli, 2012). G. Aras presents evidence on the relationship between corporate governance and operating performance in banks using a sample of 107 banks in Russia and fifty banks in Ukraine surveyed by International Financial Corporation in 2003-2006. The author finds some significant, but modest, relationships between governance and contemporaneous operating performance and a largely not significant link with the subsequent performance. The scientist concludes that aside from the popularity of corporate governance in public discussion, it has at best a second-order effect on operating performance in Russian and Ukrainian banks (Aras, 2015).

The spread of globalization raises the issue for good corporate governance performance. It set the number of questions towards global and country system of monitoring, accountability improvement, and new system establishment. Good corporate governance is associated with reduced risk for financial crisis. The better quality of shareholder protection demonstrates the dependence with the large size of the country's stock market. The weak corporate governance leads to higher costs of capital. In case of better corporate governance there is higher returns on assets.

American and Western European corporate governance systems create sound information and focus executive and managerial attention on corporate performance. After the high-profile collapse of a number of large corporations in the past two decades, several of which involved accounting fraud, there has been a renewed public interest in how modern corporations practice governance, particularly regarding accounting. The positive features of these models implementation to East European countries would reduce the insider effect and increase the fairness, transparency, accountability of value distribution, and raise corporate control in the company. The scientists propose to learn how to respect shareholders rights and exercise those rights in the corporation. 


\section{Literature review}

The formation of corporate governance system is the crucial question for all governments in transition. The privatization of large and small enterprises was typical feature of command system transformation. The problem of redistribution of property rights between insiders and outsiders, and external investors' access to privatized property is vital item of reforms. The chief goal of current corporate governance is to eliminate contradictions among shareholders and management.

One group of scientists emphasizes the regulatory role of corporations and governance system. R. Monks, $\mathrm{N}$. Minow define corporate governance system as the whole set of regulatory, market stakeholder and internal governance (Monks, Minow, 2011). Following this approach scientists Z. Bodie, A. Kane, A. Marcus consider that the corporate governance is "the set of rules and procedures that ensure that managers do indeed employ the principles of value-based management, to make sure that the key shareholder objective (wealth maximization) is implemented" (Bodie et al., 2011). The agency cost approach refers to instances when an agent's behavior has deviated from principal's interest. There are various conflicts of interests that can impact manager's decision making process to act in shareholders interests. Management can buy other companies to expand power. They can manipulate financial figures to optimize bonuses and stock-price-related options.

M. Ehrhardt and E. Brigham point out the interdependence of the sub-prime mortgage market to the financial and global economic crisis, and analyze the effect of profit maximization mechanism for a firm's value (Ehrhardt, Brigham, 2011a, b). From the financial point of view the authors point out the basic features of corporate governance that include the set of laws, rules, and procedures that influence a company's operations, and the decisions made by its managers. A. Carroll and A. Buchholtz give the overview how effective business decision makers balance, and protect the interests of various stakeholders, including investors, employees, the community, and the environment - particularly as business recovers from a perilous financial period (Carroll, Buchholtz, 2009). They give a broad definition of corporate governance including "the method by which a firm is being governed, directed, administered, or controlled... is concerned with the relative roles, rights, and accountability of such stakeholder groups as owners, boards of directors, managers, employees, and other stakeholders". The authors prove content emphasizes the social, legal, political, and ethical responsibilities of a business to both external and internal stakeholder groups, and balance strong coverage of ethics and the stakeholder model with a new focus on one of business' most recent, urgent mandates: sustainability.

Another group of scientists studies the degree to which shareholders influence and share in short- and long-term corporate value creation, and defines the goal of economic reform in transition and, largely, its pace. Shareholder access to such created value is determined by the degree to which key corporate "insiders", especially executives and management, can claim a disproportionate share of corporate value (the "insider effect)".

L. Bebchuk, A. Cohen, A. Ferrell investigate which provisions, among a set of twenty-four governance provisions followed by the Investor Responsibility Research Center (IRRC), are correlated with firm value and stockholder returns ( Bebchuk et al., 2009). The authors put forward an entrenchment index based on six provisions - four constitutional provisions that prevent a majority of shareholders from having their way (staggered boards, limits to shareholder bylaw amendments, supermajority requirements for mergers, and supermajority requirements for charter amendments), and two takeover readiness provisions that boards put in place to be ready for a hostile takeover (poison pills and golden parachutes). Bebchuk, Cohen, Ferrell find that increases in the level of this index 
are monotonically associated with economically significant reductions in firm valuation, as measured by Tobin's $Q$, and present suggestive evidence that the entrenching provisions cause lower firm valuation.

D. Lacoste, S. Lavigne, E. Rigamonti consider the relationship between ownership structure and corporate diversification strategy (Lacoste et al., 2010). Their research shows an increase in managerial ownership, far from leading to alignment, leads to managerial behavior that goes against the interests of shareholders and more precisely to unrelated diversification strategies.

The analysis of the publications confirms that the definition, value creation, and stock distribution create incentives for company development. It is important to point out the basic elements of corporate governance system which include Board of directors, charter provisions affecting takeovers, compensation plans, capital structure choices, and internal accounting control systems. The function of Board of Directors is directed to provide control of management.

Profit sharing is considered one of the important formal measure of income increase. The profit share is distributed to managers and employees which provide incentives to shareholders. In case of shares distribution within the company shareholders get benefits to ensure the company development. The forms of stock distribution and stock options could be applied for enhancing of profit increase. In case of using stock options shareholder can buy stocks in some day on specified date. Profitability increase is the key issue for shareholders. It makes it applicable for company workers interests. Stock value is connected with resources belonging to shareholders. The higher rate of return of the company is, the more it will have a stock. Empirical studies found that countries with controlling shareholder systems cause different levels of private benefit extraction. As instance, Mexican controlling shareholders are said to expropriate more than a third of the value of the company, while expropriation by their Swedish counterparts is limited to $1 \%$ of company value.

The managers and stockholders interests conflict is based on the differences of objectives, interests, methods of achievement, and benefits. Managers are concentrated on personal compensation, their own stability and stability of employment. Managerial compensation includes retaining competent managers, and aligning managers' interests with stockholders as much as it is possible. Annual salary plus performance bonuses and company shares are forms of managerial compensation. Managers try to minimize their own risk, to expand their personal power, to receive potential and financial advancement, to compete between managers, and to separate between managers' personal and professional. Stockholders are oriented on stable return, profit maximization, share price appreciation, and company stability. They wish to reduce risk, to provide consistency policy of the flow of benefits in the firm, to increase share appropriation and dividends. In order to minimize or to avoid the managers and shareholders interests conflict there is a need to create management criteria which effect stockholders.

The quality assessment of corporate management could be provided from the side of requirements and objectives for work of management institutions of the company, procedures of decision making or reporting system. The effective corporate management supposes instrument of trust creation. It helps company to get resources for successful strategy implementation, to provide a stable long-term business development, and reduce risks connected with conflicts of interests or external threats.

\section{Hypothesis and research design}

The corporate sector development demonstrates the use of mixed model in Ukraine, based partly on the principals of American and German models of corporate governance on the application. The corporate governance 
model is based on the diverse capital structure in Ukraine. It defines the large variety of shareholders, including state, institutional investors and individual stockholders. The corporate governance structure specifies the distribution of rights and responsibilities among in the corporation. The board of directors, managers, shareholders and other stockholders take part in the elaboration rules and procedures for making decisions. Good corporate governance is associated with sustainable company's value creation in a global scale. Where some of which will flow to investors with reduced risk of global financial crisis. The better the quality of shareholder protection means the larger the country's stock market. Weak corporate governance leads to higher costs of capital and in case of better corporate governance is higher returns on assets.

The panel data model from 2003 to 2005 on ownership change and privatization for 27 Ukrainian regions, including 24 oblasts, the Autonomous Republic of Crimea and the two cities Kyiv and Sevastopol demonstrates that the pace of privatization in the industrial regions with high urbanization is higher in comparison to agrarian regions in Ukraine (Nosova, Bartels, 2006). For example, the share of privatized state property is correlated with the size of the regions, measured by urban population. Wages are estimated higher in regions where more public companies were privatized. It confirms that the privatization of public owned companies may have a positive effect on wages.

The definition of value added through the companies' governance system and allocation of value added among stockholders influence value creation within the company and their disposable. The lack of the formal institutions causes the appearance of the informal forms of relations among companies, banks, and representatives of the state authorities. The dissemination of the informal rules for companies' behavior results in the disclosures and frauds appearance in corporate sector in Ukraine. The absence of the long-term corporate control policy summons an ineffective system of corporate governance formation. The existence of weak-enforcement of company's law gives an opportunity for managers to manipulate the insider information for personal interests, and as a result of it to gain an additional profit. Managers block the access of domestic and foreign investors to companies' shareholding process. The weak enforcement mechanism in Ukraine enhances the legal use of corporate rules, and new laws on bankruptcy and foreign investment.

The motivation mechanism for shareholders dividends is not created in Ukraine. An absence of dividends return mechanism and an undeveloped stock market do not stimulate shareholders and managers interests for profit maximization. Managers do not have incentives to take care for the dispersed shareholders' interests. The significant role belongs to supervisors who set targets for the risk exposure of public funds, explain any deviations from the targets, and give a corrective actions plan.

An absence of legal mechanism for bank access to company's shareholding, weak stock market development, undeveloped financial infrastructure, the lack of transparency, low control level of managers are considered as the typical features of modern corporate governance model in Ukraine. The short-term shareholders interests predominate in decision making process for company development. The data analysis of the Table 1 depicts that oligarchs have the biggest number of majority controlled stocks and the lowest average corporate governance score of any majority group. They control supervisory boards \& audit commissions, executive management and corporate communications professionals. Finance \& Credit Group's IPO of Ferrexpo on the main market of the London Stock Exchange in June 2007 remains the largest placement by a Ukrainian company. 
Tahle 1. Majority ownership structure of Ukrainian equity market

\begin{tabular}{lccc}
\hline \multicolumn{1}{c}{ Ownership type } & $\begin{array}{c}\text { Number of majority } \\
\text { controlled stocks }\end{array}$ & $\begin{array}{c}\text { Percent majority } \\
\text { controlled of total }\end{array}$ & $\begin{array}{c}\text { Average corporate } \\
\text { governance rating }\end{array}$ \\
\hline Management & 24 & 21.1 & 6.7 \\
TNC & 9 & 7.9 & 6.4 \\
Other & 11 & 9.6 & 5.5 \\
State & 19 & 16.7 & 4.7 \\
Oligarch & 51 & 44.7 & 4.2 \\
\hline All & 114 & 100.0 & 5.2 \\
\hline
\end{tabular}

Note: This chat covers the 114 stocks that received corporate governance ratings in this report.

Source: Corporate Governance in Ukraine (2011).

The concentration of ownership in the hands of financial industrial groups, diffusion of ownership among shareholders, the prevalence of closed joint-stock companies, and the removal of the company control to management are the distinctive features of the corporate governance model in Ukraine. The data of State Statistics Committee prove the hypothesis for prevalence of closed joint-stock companies to opened joint-stock companies in Ukraine during the period from 2005 to 2013. There are registered 12965 joint stock companies of different ownership forms in 2013 in Ukraine. They include 2366 opened joint stock companies, 5433 closed joint stock companies. There are 3067 joint stock companies which do not conclude the procedure of re-registering the ownership form after adoption the new Joint Stock Companies Law of 2008.

Corporate governance is the system of behavior rules used to direct and control stock company. The dispersed property disposable model is one of the typical forms of corporate governance system in Ukraine. Management provides opportunistic behavior towards shareholders. Managers combine at the simultaneously managerial and owners functions. They obtain free access to internal company's information and maximize benefits. Managers succeed to set the inside control over company, manage the company and withdraw some part of company's assets. The contrary of short-term managerial interests and long-term company' performance causes the conflict among the insiders and outside company's owners. It results in the destruction of company's balance structure and bankruptcy (Nosova, Bartels, 2006).

The typical features of corporate governance model in Ukraine are the following: the concentration of ownership in the hands of financial industrial groups, the absence of dividend payments, and lack stimulus for shareholders and managers to increase profit, and etc. The prevalence of closed joint - stock companies and the removal of the company control to management are the characteristics of "insider corporate governance model" in Ukraine. The active monitoring of executive performance is availability or reliability of relevant data is the most key question of creation transparency in corporate sector in Ukraine.

The degree of management autonomy depends on their role in decision making process, and manager's responsibilities within the company. Better operational performance leads to better allocation of resources and better management in the company. The good corporate governance would lead to the wealth creation, and results in profit maximization generated by the company. The comparison of managers and shareholders objectives, interests, benefits could be seen in the Table 2. Shareholders usually concede most of their control rights to managers. Asymmetrical access to company information enforces management to use its monopoly - the owner of the company's internal information, and manipulate it for getting profit. 
Managers act through limiting interests of shareholders. Management can engage in self-dealing, entering transactions for personal enrichment. They can purchase other companies to expand individual power instead of maximization of value of company stock. The manipulation of financial indices can be provided for bonuses optimization and stock-price benefits accumulation. The use of shadow schemes of formation and removal of funds from the investment process help to raise significant funds from the turnover.

Table 2. The comparison of managers and shareholders objectives, interests, benefits

\begin{tabular}{|c|c|c|c|}
\hline No. & Features & Managers & Stockholders \\
\hline 1. & Objective & personal compensation, stability of employment & stable return, share price appreciation, company stability \\
\hline 2. & Interests & company stability, personal stability & profit maximization, dividends \\
\hline 3. & Benefits & wage & share price appreciation \\
\hline 4. & Management decisions & $\begin{array}{l}\text { management focuses its activities in one company. } \\
\text { minimize risks }\end{array}$ & $\begin{array}{l}\text { owners invest part of capital in the company. diversify } \\
\text { risks }\end{array}$ \\
\hline & Company control & $\begin{array}{l}\text { partial control of the company and participation in } \\
\text { profit distribution }\end{array}$ & $\begin{array}{l}\text { control of the company is small, do not take responsibility } \\
\text { for results of management }\end{array}$ \\
\hline
\end{tabular}

Source: author's approach.

The managerial property concentration results in the conflict of proprietors' interests. It leads to property distribution among various companies' participants. There is a lack of enforcement mechanism for boosting efficiency through management incentives. The government influences managers' and directors' appointment. Empirical surveys of companies suggest that chief executives do not have stimulus to maximize long-term wealth of the company.

Uncertainty and high investment risk demonstrate the choice of western companies to list their shares on a stock market with strict corporate governance rules. Decrease and elimination of managers impact on decision making process of shareholders' are considered an important issue in creating good corporate governance system. The corporate governance structure is divided on three stages: Supervision Council, general meeting of stockholders, auditing committee in Ukraine. The corporate governance mechanism is based on the election and the appointment of all bodies, achieving the managers' and stockholders' interests balance, community interests' satisfaction. The concept of corporate governance is proposed in the Decree "On the Measures to Corporate Governance Development in Joint Stock Companies" in Ukraine in 2002. The Decree provides on mandatory notification of an intention to acquire a majority shareholding, a special procedure for a company to enter into contracts that may significantly affect its financial performance, administrative liability of a company's officers for violation of shareholder rights, and participation of shareholders in bankruptcy proceedings. Shareholder rights violations are most frequently connected with insufficient access to corporate information by investors. The Decree specifically addresses to disclosure and transparency issues. The Decree envisages the establishment of a Coordination Council on Corporate Governance Issues in Joint Stock Companies, and the State Securities and Stock Market Commission (SSMC). The authority and institutions provide development of the Corporate Governance Code. The Civil Code introduces a rule targeting a conflict of interest transaction between the company and shareholder in 2004. The shareholder does not have a right to vote at the general meeting on decisions regarding a transaction or dispute between the company and shareholder. In the Commercial Code there are introduced special rules 
governing liability of controlling shareholders to the company and its creditors. In case the company the company enters into a transaction on favorable terms through the fault of its controlling shareholder, such shareholder may be liable for the resulting losses. A new the JSC Law came into force in October 2008 and fully applies starting May 2011. The adoption of the JSC Law is a significant step towards the establishment of a comprehensive corporate governance regime. Joint Stock Companies Act, 2008 Chapters VII-X defines the feature of corporate governance in Ukraine. Section "General Meeting of JSC" defines the competence, procedure of general shareholders meeting, voting procedure, etc. The section Company's Executive Body includes the basic principles of the executive body activities. Evolution from formal supervisory board in Ukraine to a new model of corporate governance system supposes annual shareholders meeting, Board of Directors, supervisory board, audit committee, control board and etc. The internal and external controls are directed to be a control tool for internal management of the company. JSC Law enhances protection of rights and interests of shareholders, creating new impediments to raider attacks, and solving problems and curing irregularities arising in the corporate governance area upon implementation of the JSC Law. The Law "On Accounting and Financial Reporting in Ukraine" (1999) amended in 2011. The basic principle prevalence of substance over form.

Shareholders delegate administrative rights and responsibilities to managers for organizing intra-corporate activity. The ownership concentrates in the closed joint-stock companies. The state retains a controlling stake for most of the large companies. The transition to the "insider" management model is accompanied with a concentration of ownership in the hands of managers. There is an absence of institutional constraints. It leads to the manipulation of companies' assets through self-enrichment of intermediary structures. Poor development of the stock market limits and prevents the normal organization of corporate governance system in Ukraine.

Ease of doing business ranking in 2015 demonstrates that Ukraine gets 96 place with score 61.52 in comparison with Poland which is ranked 32 with score 73.56. The data analysis of ease of doing business in 2014 and 2015 demonstrates the improvement in starting business, registering property, and paying taxes in Ukraine (Table 3).

Tahle 3. The ease of doing business in the Ukraine

\begin{tabular}{lccc}
\hline \multicolumn{1}{c}{ Rank } & Doing Business -2015 Ranks & Doing Business - 2014 Ranks & Change in Ranks \\
\hline Ease of doing business & 76 & 69 & -7 \\
Dealing with construction permits & 70 & 68 & -2 \\
Getting electricity & 185 & 182 & -3 \\
Registering property & 59 & 88 & 29 \\
Getting credit & 17 & 14 & -3 \\
Protecting minority investors & 109 & 107 & -2 \\
Paying taxes & 108 & 157 & 49 \\
Trading across borders & 43 & 44 & 1 \\
Enforcing contracts & 70 & & -29 \\
Resolving insolvency & 142 & 141 & 1 \\
\hline
\end{tabular}

Source: Doing Business (2015).

In accordance with data of the National Bank of Ukraine foreign direct investment (FDI) decreased to US \$346 million in the first quarter of 2015 from US \$ 556 million in the first quarter of 2014. FDI in Ukraine averaged 
US $\$ 1,055.77$ million from 1998 until 2015 , reaching an all-time high of US $\$ 6,502$ million in the fourth quarter of 2005 and a record low of - US \$ 589 million in the first quarter of 2014.

In the "Top - 500 best companies" Ukrainian companies achieved a total revenue of EUR 87.2 million in 2013. Ukraine ranked second in terms of companies' revenue growth. Ukrainian companies included in the rating posted an increase in their revenues, thus demonstrating higher growth dynamics compared to the region as a whole. The average increase in the income of all included in the Top 500 at year-end companies amounted $3.26 \%$. The Ukrainian energy company DTEK entered the first time in the Top 10 companies. It had a $125.3 \%$ increase in revenue, which moved the company all the way from 32nd to 7 th place. 39 out of 51 Ukrainian companies included in the rating posted an increase in their revenues. They demonstrated higher growth dynamics compared to the region as a whole. In the Forbes rating of the largest 200 companies metallurgy was the most profitable branch. During the first half of 2014 total revenue of metallurgical enterprises exceeded 168 billion hryvnia. Four metallurgical companies entered in the top ten companies which received the maximum revenue. According to a study conducted by the "Headhunter Ukraine" the largest share of the enterprises, the crisis has forced them to optimize their costs, companies have made in the field of construction and real estate in 2014. Companies working in the field of information technology, have created the most favorable conditions for the preservation of their employees.

The corporatization process is characterized by excretion of shares of high real value from financial turnover, and poor dividends' mechanism. There is an absence of shareholders' confidence in future company development. Management experts hire auditors. One person (stockholder) combines posts of the company management and membership on the board of directors. This leads to an increase of agency costs of corporation. All of the above mentioned forms are the basis for abuses in the corporate sector, and the excretion of the shares from turnover of securities.

M. Caron, A. Fiçici, C. Richter estimate a relationship between levels of corruption and their effects on corporate governance practices present in rapidly developing economies (RDEs). They examine the level of compliance with corporate governance standards and the pervasive effects of corruption on the governance processes of firms with specific regard to RDEs, and offer comparisons and similarities of shared characteristics among these countries (Caron et al., 2012).

The representative study of 625 Ukrainian enterprises showed that corruption seemed not to be a significant problem for most business operations regardless of region, industry, or firm size in 2013. Corruption had simply become a part of the system, and businesspeople have learned how to deal with it (Denisova-Schmidt, Huber, 2014). The new representative study of 120 Ukrainian companies, conducted in early 2015 in the western part of Ukraine, shows the new tendency: corruption has become an obstacle for the majority of the companies that participated in the survey. The survey yielded some very interesting results. On the one hand, businesses are still using or even increasing their usage of certain corrupt practices; on the other hand, they indicate a significantly more negative attitude to corruption as the usual way of doing business in Ukraine. The number of businesses that view corruption as an obstacle for their development has almost doubled since 2013 , from $23 \%$ to $43 \%$ (Denisova-Schmidt, Huber, 2014). The authors consider that continuing systemic changes in Ukraine, the reformation of the Ukrainian economy and constant anti-corruption measures will push the Ukrainian business community from their current "bad" long-term equilibrium of rent-seeking behavior to a "good," corruption-free equilibrium of a win-win business game. 
The corporate governance problem includes the lack of protection mechanism for stockholders rights, the insufficient information of stock company activity, non-fulfillment stockholders general meeting decisions in the Ukraine. Corporate conflicts demonstrate an absence of administrative and criminal responsibility. The number of corporate conflicts is still high in the Ukraine. The typical forms of corporate conflicts combine the reorganization of washing up assets by company, and its property alienation to fictitious proprietors. The stockholders rights violation suggests an absence of personal timely information of vote registered shares. The lack of company transparency causes the additional risks. The government blocks the decision making process of additional shares emission. The problem of corporate rights determination, corporate governance law adoption, and stable legal system formation are the most discussed questions in the national legislation. The precise definition of the list of companies and transparent auction principals will be directed to correct the unfair results of mass privatization in the Ukraine. Investment companies experts estimate index of mergers and acquisitions (M\&A) ranged from $\$$ US 3 billion to \$ US 7.5 billion in 2008-2010 in Ukraine. According to the "Anti-Raider Union of Entrepreneurs of Ukraine" there are about 40-50 specialized raider groups in the country. The average raider gains high level of profit.

A survey by McKinsey and Company found that investors are willing to pay a premium for companies that demonstrate sound corporate governance systems. Among the survey's options for improving performance, the one selected by the most respondents was to spend more time on company matters, both at formal meetings and through informal contact. More time overall would presumably help directors cope with core governance and compliance duties and still be able to deal with strategy, risk, and talent issues more thoroughly than before. Being credible businesses that can withstand the scrutiny of international investors is more than just a matter of global marketing: it has become essential for local companies to grow and prosper. Good corporate governance is not merely fertilizes healthy growth; it is a shield against widespread financial crisis.

The current corporate governance model should be based on sufficient conditions of enterprise development, internal governance structures formation, and balance of different shareholders' interests. The effective corporate governance model considers the management functions division, the independence and responsibilities of the Board of Directors, defense of shareholders rights and interests. Transparency and transferability information, high corporate culture in the society leads to the good corporate governance system. The effectiveness of corporate governance system depends on the formation of strong shareholders' interests in future company's performance, and will lead to to company's profit maximization and in total benefits of national economy.

\section{Corporate governance conflict resolution in Ukraine}

The corporate conflict of interest may take place between the company and its stockholder, between the stockholder and the hired management, or between the company's shareholders. The objective basis for conflicts are the contradiction of the definitions of ownership as the share, determining ownership of the company, and share, defining as document, settling of stockholder rights. The basic problem deals with contradiction of ownership and management functions of the corporation. Passivity of shareholders supposes an absence of the management motivation which is explained by the high capital dispersion among the owners. There is low investment attractiveness for small investors. The contradiction among the different groups of investors, the executive and supervisory board hampers to improve an efficiency of corporate governance.

Shareholder interests are served when management is highly motivated to strive for higher productivity and better performance. It results in the company's value added increment. Conflicts between management and 
shareholders are arisen and resolved constantly in the company. The managers' withdrawal of a part of company' resources for own needs is considered one of the most important conflicts. It decreases significantly wealth of the company. Rydyk (2004) emphasizes, that "activity of corporation is the catalyst of agency conflicts. For example, as soon as in structure of the capital of corporation there is a debt loading then there is an agency conflict between shareholders and bond's holders". The managers' activity contains an opportunity of agency problems emergence. They are connected to a possibility of majority unpredictable situations existence. Managers make smaller efforts for the company's management that explains their desire to reduce up to minimum a probability of adverse consequences losses due to world market conditions change. They are guided via a choice of smaller investment horizon of the company's development. It is dealt with the restriction of the long-term company's strategy development definition. Managers try to decrease a probability of some inefficient decisions implementation. Management activity is directed on reduction of probability risk takers strategy. The following policy is directed to avoid political, investment, financial, and also random factors: uncertainty and unpredictability in the world financial markets. Managers are not interested in an effective utilization of the company's assets. An absence of personal managers' activity stimulus is a favorable basis for agency problems emergence. The management activity does not aspire to achieve profit maximization of decision-making process within the company. Jensen, Mecking (1976) conduct the analysis of the US and UK corporate sector development. They argue that in case of ownership diffusion, as is typical for US and UK corporations, agency problems stem from the conflicts of interests between outside shareholders and managers who own an insignificant amount of equity in the firm. In case of one owner (or a few owners acting together) the problem of monitor and discipline management shifts to better company's performance under decreasing of information asymmetries.

The state does not play an important role in company's monitoring or bank's reorganization. Uncertainty and high investment risk demonstrate the choice of western companies to list their shares on a stock market with strict corporate governance rules. Legal definition, legality observances are considered to form a guarantee basis for the property rights protection, a financial transparency maintenance, stability, and economic development predictability in a society. The decrease managers' control in the company, shareholders' access to decision making process relate to an important issue in creating good corporate governance system.

Classification of conflicts by the objectives pursued by the attacker is divided on the following groups:

- a controlling share of conflicting investor is obtained to form horizontally or vertically integrated holding company,

- consolidation of a large share made for the purpose of speculative sale of a controlling share to a strategic investor,

- investor takeover to take control of the company - the attack object,

- the acquisition of a controlling stake to block a competitor (Osipenko, 2004).

According to the criterion of object-conflict is divided into significant minority shareholders, the majority shareholder; shareholders against management; the conflict between the general meeting and the board of directors; contradiction between management and the workforce when the latter holds a significant share.

The concept of conflict of interest is defined in Ukrainian legislation. It is incorporated into the laws "On the Procedure for Settlement of Collective Labor Disputes (Conflicts)" and "On the Procedure for Repayment of Taxpayer Liabilities to Budgets and State Target Funds", and the State Commission for Securities and Stock Market in its Principles of Corporate Governance. In the Ukrainian Principles of Corporate Governance the conflict of 
interest is defined exactly as "the discrepancy between the personal interests of an officer or his/her connected persons and the professional duty to act in the best interests of the company".

The distinctive features of corporate conflicts are their subjective components. It grounds for their appearance as specific settlement procedures. The corporate conflicts are the way to secure the operation of the company in the interests of all its owners (participants). The aim of corporate relations is to ensure a balance of interests. Different factors may serve ground for the corporate conflicts, but for convenience the factors in general can be divided into four groups: appearance of the interest groups of owners in the ownership structure of the company; related party transactions conducted by the company; presence of the persons aimed at using methods that are traditionally referred as "raiding" among the owners of the company; corporate restructuring or change of control structure in the company.

The current Ukrainian legislation specifies a number of legal mechanisms for corporate conflicts prevention, and their negative effects to minimization. In Ukrainian legislation on joint stock companies such mechanisms are summarized in the following: 1) internal corporate mechanisms for conflict resolution; 2) contract mechanisms; 3) judicial and non-judicial (alternative) mechanisms. The first group includes the codes of corporate governance, the internal conflict of interest policies and specific procedures stipulated by the Law of Ukraine "On Joint Stock Companies" (2008). The Principles of Corporate Governance, approved by the decision No 571 of 11.12 .2003 of the State Commission for Securities and Stock Market are the basis for its development. Prevention of corporate conflicts is one of the objectives of such code. The code defines the internal procedures to identify corporate conflict, to inform the company about, and to resolve conflict. The law sets out special procedures designed to resolve the conflict of interest between shareholders.

The second group explains the difference of the buy-out agreement and shareholders' agreement in the Ukrainian legislation. The main difference between these agreements is the narrow scope of regulation. The buyout agreement indicates only the conditions and mechanisms of the shareholder's withdrawal from the business or of a squeeze-out, determining voluntary or mandatory buy-out, as well as the existence of third parties rights in connection with the buy-out. The shareholders' agreement regulates such issues as the nomination of candidates for management positions, the procedures for stock disposal and stock pledge, voting procedures, the procedures for dispute resolution and responsibility for infraction of obligations.

In fact, in spite of the prohibition of the Supreme Court of Ukraine and the High Commercial Court of Ukraine, the corporate relations in the Ukrainian companies are frequently regulated outside Ukraine. T. Bondaryev, M. Malskyy (2008) support conclusions that the Supreme Commercial Court of Ukraine has acted in unusual manner in some cases for courts in developed countries.

The third group provides mechanisms for arbitration within national or foreign (international) institutions at different levels and complexity. These include the mediation along with the procedures that are governed by internal conflict resolution policy of the company.

The legal mechanism for conflict resolution includes the list of measures to be fulfilled. The responsibility of the board provides realization of structures for achievement of balance between the pressure of accountability and the requirement of noninterference, development of capable institutions for financing, monitoring and controlling corporate enterprises. 


\section{Conclusions}

The consequences of global financial crisis are resulting in some financial institutions bankruptcy, the bailout of banks by national governments, and downturns in stock markets around the world. The corporate governance analysis of various theories suggests two main approaches: the definition through the companies' governance system, and the determination of the allocation of value added among stockholders. The rest includes the adoption of the international standards of corporate governance system all over the world.

The article attempts to establish a conceptual framework for the study of corporate governance by employing the agency theory, the rational choice institutionalism, and enforcement theory. One group of scientists emphasizes the regulatory role of corporations and governance system, and defines corporate governance system as the whole set of regulatory, market stakeholder and internal governance. Another group of scientists studies the degree to which shareholders influence and share in short- and long-term corporate value creation, and defines the goal of economic reform in transition and, largely, its pace.

The goal of corporate governance is to eliminate cases when stockholders have conflicts of interest with one another. The application of the legal mechanisms to prevent corporate conflicts and to minimize their negative effects will be directed to align of managers' behavior with stockholders.

1. Adopt the principles of independence, responsibility, and transparency in corporate management, process and records. Transition to a new corporate governance system, inspired by the principles of FASB, IASB and the Sarbanes-Oxley Act, will force transparency and timely reporting of corporate business activities. In turn, these practices will enforce independence and accountability in decision making and strengthen investor confidence.

2. The modern model of corporate governance system includes the separation of the functions of management and owners, independence and accountability of board members, the protection of minority shareholders rights, transparency and timely transmission of information on the activities of the company, maintaining a high level of corporate culture in the society.

3. The problem of institutional rights establishment relates to the crucial problem for investment decisions. Business environment improvement will stimulate institutional development via credibility, transferability of shareholders rights, legal mechanisms for preventing corporate conflicts, and minimize their negative effects. Stock market and financial institutions development will stimulate foreign direct investment inflow into the countries.

4. Increased liquidity and exchange rate stabilization will help to restore confidence in the banking system. Creation an attractive environment for investment in Ukrainian securities, guarantee investors rights will provide a base for raising funds in the corporate sector.

\section{References}

Aras, G. (2015). Corporate and capital market governance in emerging economies. Emerging markets finance and trade, 51, Suppl. 2. Bebchuk, L., Cohen, A. \& Ferrell, A. (2009). What matters in corporate governance? Journal of Financial Studies, 22 (2): 782-827. Bodie Z., Kane, A. \& Marcus, A. (2011). Investments. 8th ed. New York, NY: McGrawHill Higher Education.

Bondaryev, T. \& Malskyy, M. (2008). Recent Developments concerning Dispute Resolution of Shareholder Agreements in Ukraine: For Better or for Worse. Stockholm International Arbitration Review, 3.

Caron, M.I., Fiçici, A. \& Richter, C.L. (2012). The influence of corruption on corporate governance standards: shared characteristics of rapidly developing economies. Emerging Markets Journal, 2.

Carroll, A.B. \& Buchholtz, A.K. (2012). Business and Society, Ethics and Stakeholder Management. 8th ed. Mason, OH: South-Western Cengage Learning. 
Corporate Governance in Ukraine (2011). Concorde Capital Research. USAID, October.

Denisova-Schmidt, E. \& Prytula, Y. (2015). The business environment in Ukraine: new country, old problems, more hope. Harvard University. Edmond J. Safra Center for Ethics, April 29.

Doing Business (2013). Smarter Regulations for Small and Medium-Size Enterprises. International Bank for Reconstruction and Development-The World Bank. 10th ed.

Doing Business (2015). Going Beyond Efficiency. Economy Profile. Ukraine. The International Bank for Reconstruction and Development-The World Bank.

Ease of Doing Business (2015). World Bank. International Financial Corporation. Available at: www.doingbusiness.org/data/ exploreeconomies/ukraine.

Ehrhardt, M.C. \& Brigham, E.F. (2011a). Corporate Finance. 4th ed. South-Western Cengage Learning.

Ehrhardt, M.C. \& Brigham, E.F. (2011b). Financial Management: Theory and Practice. 13th ed. Mason, OH: South-Western Cengage Learning.

Governance since the economic crisis: McKinsey Global Survey results (2011). McKinsey \& Company. July. Available at: www.mckinsey. com/insights/leading_in_the_21st_century/governance_since_the_economic_crisis_mckinsey_global_survey_results.

Jensen, M. (2010). Value Maximization, Stakeholder Theory, and the Corporate Objective Function. Journal of Applied Corporate Finance, 1.

Keasey, K., Thompson, S. \& Wright, M. (2005). Corporate Governance: Accountability, Enterprise and International Comparisons. Wiley and Sons.

Lacoste, D., Lavigne, S. \& Rigamonti, E. (2010). Do Monitoring and Alignment Mechanisms Influence Diversification Strategies? The Case of French Companies. Management, 13 (5): 342-365.

Monks, R. \& Minow, N. (2011). Corporate governance and the Global Financial Crisis: International Perspectives. Ed. W. Sun, J. Stewart, D. Pollard. Cambridge University Press.

Myers, P.M. \& Zouaghi-Maulet, N. (2011). Crossing the Pond in Search of Better Executive Compensation Practices. Corporate Governance Advisor. Business Source Premier, 19 (2): 12-19.

Neil, B. (2013). Top 10 Global Compliance Trends to Watch in 2013. Compliance Week, January: 40-41.

Nosova, O. \& Bartels, K. (2006). Statistical Analysis of the Corporate Governance System in the Ukraine: Problems and Development Perspectives. Statistische Diskussionsbeiträge. Journal of Potsdam University, 25.

Ojah, K. \& Mokoaleli-Mokoteli, T. (2012). Internet financial reporting, infrastructures and corporate governance: an international analysis. Review of Development Finance, 2: 69-83. Available at: www.sciencedirect.com.

Oliver, H. (1995). Corporate Governance: Some Theory and Implications. Economic Journal,105: 678-689.

On joint stock companies: The Law of Ukraine on September 17 No. 514-VI (2008). Bulletin of the Verkhovna Rada of Ukraine, 50-51: Art. 384.

Osipenko, O. (2004). Corporate Governance Institutions and Joint Stock Companies Conflicts in Russia. Moscow: IKF "EKMOS".

Shleifer, A. \& Vishny, R.W. (1997). A Survey of Corporate Governance. Journal of Finance, LII (2): 737-783.

Wirtschaftsinformationsdienst der Zeitschrift OST-WEST-CONTACT zur Ukraine (2014). Dezember. Available at: www.owc.de.

Cite this article aS: Nosova, O. (2015). Corporate governance model in Ukraine: The conflict resolution problems. Szczecin University Scientific Journal, No. 883. Service Management, 16 (2): 97-110. 